\title{
Profesi Engineer dan Strategi Mengatasi Kecemasan Berbahasa Inggris
}

\author{
Suciana Wijirahayu ${ }^{1)}$, Rifki Irawan ${ }^{2)}$ \\ ${ }^{1)}$ Sekolah Pascasarjana Universitas Muhammadiyah Prof. DR. HAMKA \\ J1. Buncit Raya No. 17 Pancoran Jakarta Selatan Telp (021) 79184063 Website: uhamka.ac.id \\ ,2)Universitas PGRI Jogyakarta, Jl. PGRI Sonosewu Ngestiharjo, Kasihan, Bantul Regency. \\ Telp 087889972323, Website:www.upy.ac.id
}

\begin{abstract}
One of the reasons why the participants lack speaking skill is they felt anxious when communicating in English in a real situation, especially with foreigners. There are eight participants in this research joined in house training in one of the company in Jakarta-Indonesia The research is mainly qualitative with some descriptive statistics which employed some data collection techniques: two questionnaires, interview, classroom observation, and document analysis. The data were analyzed by ways of reducing, displaying, and interpreting data. Four participants detail expression related to their Foreign Language Anxiety (FLA) will be illustrated and discussed. The results of the study were most of the participants experience a high level of test anxiety, the sources of anxiety coming from people's view, preparation, procrastination, expectation, negative consequences/ negative thinking, personal problem, time pressure, format usage, students' age, students' familiarity with the testing condition, testing situation factors, and not mastering the skill. The participants' coping strategies are various which are mostly cooperating.
\end{abstract}

Keyword:English as a Foreign Language (EFL), Foreign Language Anxiety(FLA)

\section{Pendahuluan}

Era globalisasi menyebabkan pesatnya perkembangan teknologi komunikasi dan bahasa menjadi sarana penting dalam pengembangan dan aplikasinya.Bahasa Inggris yang menjadi salah satu bahasa globalyang digunakan secara luas sebagai bahasa internasionaldan telah berkembang menjadilingua franca, digunakan di berbagai bidang oleh profesional dan menjadi salah satu persyaratan penting tidak terkecuali dalam pengembangan profesi Engineer khususnya di bidang konstruksi sebagai kontraktor maupun supplier (pemasok) khususnya di dunia usaha.

Bagi sarjana teknik yang memilih kontraktor sebagai salah satu profesiatau karyawan perusahaan pemasok (supplier) di bidang konstruksi, menangani kegiatan berkaitan dengan layanan dalam sebuahperusahaan, kegiatan yang dimulai dari perencanaan kebutuhan untuk menyelesaikan semua aktifitas untuk memperoleh berbagai produk dan layanan merupakan keseharian. Suatu hal yang tidak dapat dihindari dalam kegiatan kerja mereka adalah bertemu dengan orang asing (ekspatriat) di bidang yang sama sebagai vendor atau klien mereka; dalam maka, bahasa Inggris perlu digunakan untuk berkomunikasi secara efektif.

Pada studi ini, dalam pekerjaan sehari-hari partisipan sering bertemu dengan beberapa klien asing dari negara lain seperti Amerika, Inggris, Australia, dan negara lainnya untuk mendapatkan proyek dalam memasok berbagai furnitur dan bahan bangunan. Sehingga mereka diharapkan dapat berkomunikasi dengan lancar dalam bahasa Inggris, membuat klien mereka terkesan dan menciptakan pemahaman dengan menjelaskan produk perusahaan yang terkait dengan kebutuhan klien mereka. Oleh karena itu penguasaan bahasa Inggris yang sangat baik adalah suatu kebutuhan bagi profesional di bidang ini[1].

Hal inilah yang membuat manajer perusahaan pada penelitian mengundang seseorangin house trainer untuk melatih karyawannya cara berbahasa Inggris dengan baik. Dia meminta tutor untuk menemukan cara untuk memotivasi karyawandan engineeruntuk menyukai bahasa Inggris dan mengurangi kecemasan mereka saat berbicara.Partisipan sangat yakin bahwa bahasa Inggris penting dalam pekerjaan mereka. Apabila mereka memiliki kemampuan bahasa Inggris yang baik terutama keterampilan berbicara, perusahaan akan memperoleh keuntungan. Salah satu keuntungannya adalah klien asing mereka akan merasa nyaman untuk berkomunikasi dengan mereka. Sebagai hasilnya, perusahaan akan mendapatkan kepercayaan lebih dari vendor dan klien sehingga dapat menciptakan hubungan yang baik untuk bekerja sama dalam proyek berikutnya.

Ketika berbicara dengan penutur asli bahasa Inggris, siswa EFL (English as a Foreign Language) cenderung mengalami kesulitan dalam memahami dirinya dan akan berbicara dengan terbata-bata atau bahkan diam 
dalam percakapan [2]. Mereka menghadapi masalah besar dalam terutama ketika mereka harus berbicara dalam bahasa target, terutama bahasa lisan dan itu berarti bahwa mereka harus belajar untuk memahami apa yang orang katakan dan mencoba untuk menyampaikan apa yang ingin mereka ungkapkan dalam kelas bahasa asing. Ini terjadi karena sebagian besar siswa percaya bahwa tidak ada yang harus dikatakan sampai dapat dikatakan dengan benar [3] "Jika siswa menyadari dia membuat kesalahan yang dapat dihindari selama tes, maka kecemasan dan kesalahan dapat meningkat"

\section{Dasar Teori}

\section{Speaking}

Brown [4]mendefinisikanspeakingsebagai keterampilan produktif yang dapat diamati baik secara langsung atau secara empiris dan dipengaruhi oleh akurasi bahasa inggris, keterampilan mendengarkan siswa,dan tes lisan.Bagi sebagian orang, agar dapat berbahasa Inggris dengan lancar, mereka merasa harus mampu mengucapkan fonem dengan benar, menggunakan pola stres dan intonasi yang tepat dan berbicara dalam percakapan. Namun demikian, berbicara adalah lebih dari hal tersebut karena berbicara adalah keterampilan produktif yang melibatkan pembicara untuk menggunakan ungkapan lisan untuk mengekspresikan makna kepada orang lain [5]. Berbicara adalah penggunaan aktif bahasa untuk mengekspresikan makna sehingga lawan bicaranya dapat memahaminyaCameron [6]. Ini berarti bahwa kemampuan untuk berbicara identik dengan pengetahuan bahasa karena ucapan adalah sarana komunikasi manusia yang paling dasar. Oleh karena itu, berbicara adalah keterampilan produktif berbahasa Inggris yang dapat diamati baik secara langsung atau secara empiris yang tidak hanya perlu mengucapkan fonem dengan benar, menggunakan pola stres dan intonasi yang sesuai dan berbicara dalam percakapan yang terhubung, tetapi juga mengekspresikan makna sehingga lawan bicaranya dapat memahaminya.

Bahasa Inggris sebagai bahasa asing dipelajari sebagai mata pelajaran sekolah yang penting dan hasil ujian digunakan sebagai prasyarat untuk melanjutkan kuliah di universitas[7]. Dia juga mengatakan bahwa beberapa orang belajar bahasa Inggris karena ingin mempunyailebih banyak peluang secara profesional di bidang mereka.Berbagai alasan tersebut akan memberikan motivasi yang berbeda dalam belajar bahasa Inggris dan pada akhirnya akan mempengaruhi hasil belajar peserta didik. Jika bahasa Inggris hanya dipelajari karena mata pelajaran di sekolah, hal tersebut tidak akan menarik siswa untuk murni mempelajarinya. Jika itu dipelajari karena kebutuhan para siswa, maka mereka akan belajar bahasa Inggris dengan sungguh-sungguhsehingga akan memberi dampak pada pencapaian dan pengembangan kemampuan bahasa Inggris mereka.

Ada beberapa prinsip dalam proses pengajaran dan pembelajaran bahasa Inggris. Prinsip-prinsip tersebut dapat mempengaruhi pencapaian bahasa siswa yang merupakan prinsip kognitif, linguistik dan afektif [4]. Kompetensi komunikatif adalah kemampuan siswa untuk menangkap berbagai makna tergantung pada situasi dan konteks. Selain domain kognitif dan linguistik, afektif juga penting dalam mempelajari bahasa karena itu adalah sisi paling mendasar dari perilaku manusia [4]. Domain afektif berkaitan dengan keterlibatan emosional yang terdiri dari perasaan tentang diri, hubungan dalam komunitas pembelajar dan ikatan emosional antara bahasa dan budaya. Oleh karena itu pada proses pengajaran dan pembelajaran yang efektif dan untuk mencapai keberhasilan, seorang guru harus memahami domain-domain tersebut. Domain afektif itu sendiri terdiri dari tiga faktor yaitu sikap, motivasi, dan tingkat kecemasan [6]. Salah satu upaya pengajar untuk memotivasi siswa dan meningkatkan efektifitas proses belajar mengajar adalah dengan menggunakan teknologi sebagai media [8]

\section{Kecemasan Berbahasa Asing(Foreign Language Anxiety)}

Beberapa orang yang memiliki pengalaman buruk dalam belajar bahasa Inggris, terutama berbicara cenderung merasa lebih cemas daripada mereka yang tidak memiliki atau beberapa pengalaman traumatis di masa lalu. Sebagai contoh, ketika seorang siswa belajar bagaimana berbicara bahasa Inggris dengan baik di SD, gurunya tidak memberinya umpan balik positif tetapi gurunya memarahinya dan membuatnya merasa trauma tentang hal itu. Dalam hal ini, siswa mengalami kecemasan bahasa.

Kecemasan adalah perasaan ketegangan dan ketakutan yang kompleks yang dapat membuat siswa tidak termotivasi untuk mempelajari bahasa dan memiliki hubungan negatif dengan pencapaian siswa Semmar in Aling [9].

Kecemasan bahasa asing adalah kompleks yang berbeda dari persepsi diri, keyakinan, perasaan dan perilaku yang terkait dengan pembelajaran bahasa kelas yang timbul dari keunikan proses pembelajaran bahasa [3].Setiap siswa memiliki tingkat kecemasan yang berbeda. Beberapa siswa memiliki kecemasan tinggi dan yang lain memiliki kecemasan rendah dan tingkat ini dipengaruhi oleh beberapa faktor (Chan \& $\mathrm{Wu}[10])$. Pertama, semakin rendah kemampuan berbahasa Inggris para pelajar, semakin tinggi tingkat kecemasannya. Keterbatasan waktu mengajar bahasa Inggris tak terhindarkan menyebabkan frustrasi guru dan kecemasan siswa; Oleh karena itu, sebagian besar guru percaya bahwa jika mereka memiliki lebih banyak waktu, efek pengajarannya dapat menjadi lebih baik. Selain itu, siswa mengalami lebih sedikit kecemasan ketika mereka menganggap diri mereka lebih kompeten[9]

Kedua,[11] ada beberapa faktor yang mempengaruhi kecemasan bahasa. Faktor - faktor tersebut adalah usia, prestasi akademik, riwayat kunjungan negara asing, pengalaman sekolah menengah sebelumnya dengan bahasa asing, rata-rata keseluruhan yang diharapkan untuk kursus bahasa saat ini, kompetensi skolastik yang dirasakan, dan harga diri yang dirasakan. Semua faktor memainkan peran utama dalam memicu atau mengurangi kecemasan bahasa.

Ketiga, motivasi, usaha, dan kemahiran bahasa Inggris memiliki pengaruh yang signifikan terhadap tingkat kecemasan siswa [11]. Faktor-faktor ini menyebabkan kecemasan mungkin sedikit berbeda dari satu konteks ke konteks lainnya.

Ada tiga sumber kecemasan bahasa asing yang ketakutan komunikasi, kegelisahan tes, dan takut evaluasi negatif [12]. Penyebab pertama kecemasan bahasa asing 
adalah ketakutan komunikasi yang berarti tingkat ketakutan atau kecemasan individu yang terkait dengan komunikasi yang nyata atau diantisipasi dengan orang lain [13]. Di ruang kelas bahasa asing, tugas lisan pembelajar bahasa mencakup tidak hanya belajar bahasa asing tetapi juga melakukan bahasa. Oleh karena itu, pemahaman komunikasi dalam konteks bahasa asing berbeda dari konteks lain. Keyakinan guru mengenalkan strategi belajar bahasa Inggris sebagai bahasa asing dalam berkomunikasi sangat dalam hal ini berpengaruh terhadap bagaimana strategi tersebut diaplikasikan di kelas [14].

Ketakutan akan evaluasi negatif terkait erat dengan pemahaman dalam komunikasi[13]. Jenis kecemasan ini biasanya terjadi dalam situasi tes, mungkin terjadi dalam situasi sosial, evaluatif seperti wawancara untuk pekerjaan atau berbicara dalam kelas bahasa asing.

Selain itu, peneliti lain [15] mengidentifikasi enam sumber utama Foreign Language Anxiety (FLA) diantaranya pada siswa, guru dan praktik pembelajaran. Dia mengungkapkan bahwa kecemasan bahasa disebabkan oleh (a) kecemasan pribadi dan antar pribadi, (b) keyakinan pembelajar tentang pembelajaran bahasa, (c) kepercayaan instruktur tentang pengajaran bahasa, (d) interaksi instruktur-pelajar, (e) prosedur kelas, dan (f) pengujian bahasa. Selain itu, Horwitz dalam Alshahrani \& Alshahrani [16] mengakui bahwa kemampuan guru yang rendah merupakan faktor utama yang berkontribusi terhadap FLA. Setiap Siswa memiliki strategi yang berbeda untuk mengurangi kecemasan mereka. Ini tidak dapat dilihat oleh kuesioner dari Horwitz [2] tetapi dapat dideteksi dengan observasi dan wawancara karena data tersebut termasuk data kualitatif. Dalam mengurangi kecemasan bahasa asing, para siswa menggunakan beberapa strategi mengatasi yang perilaku penerbangan, perilaku agresif, perilaku manipulasi kelompok, dan perilaku kompromi [17].Strategi-strategi lain yang biasa digunakan untuk mengatasi kecemasan dalam berbahasa asing diantaranya adalah flight, agressive, group dan compromise[1].

Perilaku Flight (fantasi) adalah strategi mengatasi yang dilakukan dengan bergerak menjauh atau menghindari kelas bahasa Inggris dengan keterlambatan, tidak menghadiri kelas, berdiam diri, tidak responsif dan kebosanan. Perilaku ini juga dapat dilihat dari ketidakmampuan untuk bertahan atau seringnya perubahan kelompok kelas atau bahan belajar (nomadisme). Selain itu, kita dapat mengamati perilaku ini ketika seorang peserta mengatakan bahwa dia tidak memerlukan kelas EFL, karena dia pikir dia baik dalam bahasa Inggris (melarikan diri dari kenyataan - terbang dengan fantasi).

Perilaku agresif menunjukkan ketidaksukaan untuk mempelajari keterampilan tertentu (misalnya, saya tidak suka berbicara dalam bahasa Inggris), menjengkelkan teman sekelas yang lebih lemah (meneruskan perasaan cemas terhadap seseorang yang ia rasa kurang kuat daripada dirinya sendiri- pemindahan), meremehkan EFL atau mata pelajaran lainnya, tugas atau bahkan guru (sinisme), dan mencoba menunjukkan superioritas dalam satu keterampilan tertentu untuk menghindari evaluasi negatif dari ketidakmampuan secara keseluruhan.

Perilaku manipulasi kelompok adalah semacam manifestasi kecemasan kolektif berbahasa yang ditampilkan untuk mencari pendukung di kelas dan membentuk asosiasi emosional di mana mereka melindungi dan mendukung satu sama lain (kedekatan eksklusif). Misalnya, di ruang kelas Amerika, siswa EFL Indonesia dapat membentuk kelompokkecil berbasis kewarganegaraan informal dan eksklusif dan mereka saling membantu di kelas EFL, tetapi tidak terbuka untuk siswa EFL lainnya dari negara yang berbeda.

Perilaku kompromi adalah strategi mengatasi yang biasanya ditunjukkan oleh siswa yang relatif lebih dewasa, dan dianggap sebagai tanggapan positif terhadap kecemasan berbahasa. Contoh perilaku kompromi adalah dengan belajar lebih giat (memfasilitasi kecemasan), mencari bantuan dari guru atau teman sekelas (tidak hanya menyerah, tetapi berusaha mengatasi kecemasan), dan mencoba membantu orang lain (karena dia dalam kesulitan, dia lebih siap) memahami orang lain dan bersedia membantu mereka - altruisme). Tidak seperti formasi reaksi, perilaku tersebut dilakukan kepada orang lain tanpa harapan yang jelas untuk menerima bantuan yang sama sebagai balasannya.

\section{Skala Kecemasan Kelas Bahasa Asing (FLCAS)}

Untuk mengidentifikasi dan mengukur kecemasan bahasa asing, Horwitz dkk dalam [16] mengembangkan Skala Kecemasan Kelas Bahasa Asing (FLCAS) yang terdiri dari 33 item yang meminta peserta untuk menanggapi situasi khusus untuk FLA, merefleksikan tiga komponen: ketakutan komunikasi, altruism. Kegelisahan, dan ketakutan akan evaluasi negatif. Karena tingkat tinggi validasi konstruktif dan keandalan, koefisien reliabilitasnya ditemukan berkisar antara 0,77 hingga 0,83 dalam banyak penelitian.

\section{Coping Strategies to Reduce Foreign Language Anxiety (Ehrman in Cha, 2006, p.82)}

\begin{tabular}{|c|c|c|}
\hline No. & Coping Strategies & Specifications \\
\hline \multirow[b]{2}{*}{1} & Flight & - Avoidance or withdrawal: Pulling away \\
\hline & Behaviors & $\begin{array}{l}\text { Reaction formation: Doing something for others in } \\
\text { expectation to be given a similar treatment from them } \\
\text { - Fantasy: Mental escaping from reality such as } \\
\text { daydreaming } \\
\text { - Boredom: Hiding incompetence such as trying to avoid } \\
\text { being called upon by intentionally showing indifference } \\
\text { in activities } \\
\text { - Rationalization: Attempting to justify maladaptive } \\
\text { behaviors, such as lateness or nonparticipation, by } \\
\text { substituting good reasons for real ones } \\
\text { - Generalization: Stretchirig out his particular behaviors } \\
\text { as if it is common to everybody, though not so } \\
\text { - Nomadism: Inability to stay in one place or frequent } \\
\text { changes of class group and study materials }\end{array}$ \\
\hline \multirow[t]{5}{*}{2} & $\begin{array}{l}\text { Aggressive } \\
\text { Behaviors }\end{array}$ & $\begin{array}{l}\text { - Competition: Trying to demonstrate superiority in one } \\
\text { particular area to avoid a negative evaluation of overall } \\
\text { incompetence }\end{array}$ \\
\hline & & $\begin{array}{l}\text { Displacement: Redirecting anxious feelings in a form } \\
\text { of anger toward a person whom he feels less strong than } \\
\text { himself }\end{array}$ \\
\hline & & $\begin{array}{l}\text { Cynicism or negativity: belittling ESOL or other } \\
\text { mainstream classes, assignments or even teachers }\end{array}$ \\
\hline & & $\begin{array}{l}\text { Interrogation: Keeping others under defensive by } \\
\text { giving a barrage of questions }\end{array}$ \\
\hline & & $\begin{array}{l}\text { Acting out: Express anxious feeling straightforwardly } \\
\text { and in an intense manner, such as crying }\end{array}$ \\
\hline \multirow{3}{*}{3} & Group & - Forming subgroups: Seeking out supporter(s) and \\
\hline & Manipulation & forming an emotional subgroup for mutual helps \\
\hline & Behaviors & $\begin{array}{l}\text { - Scapegoating: Keeping one person in negative spotlight } \\
\text { so that others can feel competent (as compared to him } \\
\text { or her) }\end{array}$ \\
\hline \multirow{3}{*}{4} & Compromise & - Anticipation: Seeking out for help from teachers and/or \\
\hline & Behaviors & $\begin{array}{l}\text { classmates or simply studying harder and preparing for } \\
\text { class longer often more than needed }\end{array}$ \\
\hline & & $\begin{array}{l}\text { Altruism: Trying to help others, but unlike reaction } \\
\text { formation, not expect to receive similar help in return }\end{array}$ \\
\hline
\end{tabular}




\section{Metodologi Penelitian}

Partisipan dalam penelitian ini adalah delapan karyawan sebuah perusahaan konstruksi di Jakarta dan semuanya pria. Mereka mengikuti in house trainingbahasa Inggris kelas speaking (percakapan) dan dibagi menjadi dua kelas yaitu kelas A dan B oleh manajer perusahaan tersebut. Siswa kelas percakapan kedua memiliki kemampuan bahasa Inggris yang lebih tinggi daripada kelas percakapan pertama. Berdasarkan data penelitian meskipun mereka bekerja di kantor yang sama, mereka memiliki usia, latar belakang pendidikan, pekerjaan, dan tingkat kemampuan bahasa Inggris yang berbeda. Desain penelitian ini adalah studi kasus. Data dalam penelitian ini diperoleh dari angket FLCAS, observasi dan interview.

\section{Temuan dan Pembahasan}

Temuan ada studi kasus ada penelitian ini akan dibahas berdasarkan data pada tabel berikut ini.

\begin{tabular}{|c|c|c|c|c|c|}
\hline No. & Name & Age & $\begin{array}{l}\text { Background } \\
\text { of Education }\end{array}$ & Job & English Class \\
\hline 1 & Student A1 & 23 & SMA & Delivery Staff & $\begin{array}{l}\text { Conversation } \\
1 \text { Class }\end{array}$ \\
\hline 2 & Student A2 & 24 & S1 & Drafter \& 3D Staff & $\begin{array}{c}\text { Conversation } \\
1 \text { Class }\end{array}$ \\
\hline 3 & Student A3 & 26 & SMA & Admin Workshop & $\begin{array}{l}\text { Conversation } \\
1 \text { Class }\end{array}$ \\
\hline 4 & Student B1 & 23 & S1 & $\begin{array}{c}\text { Human Research } \\
\text { Development (HRD) }\end{array}$ & $\begin{array}{c}\text { Conversation } \\
2 \text { Class }\end{array}$ \\
\hline 5 & Student B2 & 27 & S1 & Project Manager & $\begin{array}{l}\text { Conversation } \\
2 \text { Class }\end{array}$ \\
\hline 6 & Student B3 & 28 & S1 & $\begin{array}{l}\text { Health, Safety, and } \\
\text { Environment (HSE) }\end{array}$ & $\begin{array}{c}\text { Conversation } \\
2 \text { Class }\end{array}$ \\
\hline 7 & Student B4 & 26 & S1 & $\begin{array}{l}\text { Supply Chain } \\
\text { Management }\end{array}$ & $\begin{array}{l}\text { Conversation } \\
2 \text { Class }\end{array}$ \\
\hline 8 & Student B5 & 24 & S1 & IT Support & $\begin{array}{l}\text { Conversation } \\
2 \text { Class }\end{array}$ \\
\hline
\end{tabular}

Latar belakang partisipan yang mengikuti English Conversation in house Training di perusahaan jasa konstruksi tersebut di atas dan strategi yang mereka gunakan dalam mengatasi kecemasan dalam komunikasi merupakan salah satu pokok bahasan dalam studi kasus ini.

Tingkat kecemasan berbahasa asing dari delapan partisipan tergambar di tabel berikut ini. Vareasi tingkat kecemasan dan asal dari kecemasan dari masing-masing peserta khususnya A1, A2, A3 dan B1 akan dibahas lebih lanjut.

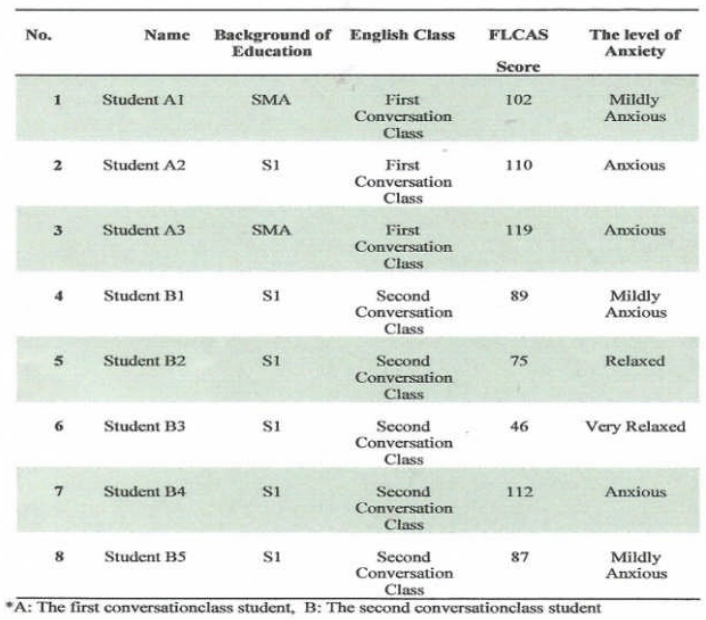

\section{Partisipan A1}

Partisipan A1 berusia dua puluh tiga tahun dan latar belakang pendidikan terakhirnya adalah sekolah menengah kejuruan otomotif yang berfokus pada pembelajaran tentang bagaimana merancang, menciptakan dan mengembangkan alat-alat transportasi darat dengan mesin, terutama sepeda motor, mobil, bus, dan truk . Program studinya menggabungkan elemen pengetahuan mekanik, listrik, elektronik, keselamatan, dan lingkungan serta matematika, fisika, kimia, biologi, dan manajemen.

A1 telah belajar bahasa Inggris sejak SMP dan telah belajar sekitar lima belas tahun di lembaga bahasa Inggris formal dan informal. Dia berpikir bahwa bahasa Inggris mudah dikuasai dan dia memiliki motivasi besar untuk mempelajarinya, jadi dia pernah bergabung kursus bahasa Inggris selama enam bulan. Dia suka bahasa Inggris karena dia pikir jika dia menguasainya, itu akan meningkatkan karirnya di masa depan. Selama belajar bahasa Inggris, ia memiliki beberapa pengalaman buruk. Ketika dia mencoba untuk berkomunikasi dengan seorang penutur bahasa Inggris yang membutuhkan informasi tentang transportasi di Jakarta, dia tidak dapat menjelaskan dengan baik karena dia tidak memiliki pengucapan bahasa Inggris dan tidak mengerti apa yang dimaksud oleh penutur asli. Namun, pengalaman itu tidak membuatnya frustrasi dalam berbahasa Inggris; di sisi lain, teman-temannya memotivasi dia untuk selalu belajar dan meningkatkan kemampuan berbahasa Inggrisnya.Karena siswa A1 mendapat skor 102 dalam hasil FLCAS yaitu antara rentang 87-107; Selain itu, dari observasi kelas selama sesi percakapan, menunjukkan beberapa gejala kecemasan danhal tersebut berasal dari kekhawatiran komunikasi.

Partisipan A1 berasumsi bahwa pemahaman komunikasi sebagai sumber utama FLA-nya karena dia takut membuat kesalahan dan kesalahan. Misalnya, ia ingin mengucapkan kata telur dalam bahasa Inggris "telur" (/ eg /) dan berumur dalam bahasa Inggris "usia" (/ eidz /). Keduanya adalah pasangan minimal dan dia menambahkan bahwa jika dia salah mengucapkan kata-kata, yang lain akan salah paham tentang makna yang dimaksudkannya. Perasaan buruk ini terus menghantuinya ketika berbicara bahasa Inggris di dalam dan di luar kegiatan kelas sebagai akibatnya, dia tampak gugup dan tidak fokus pada kegiatan berbicara, menjadi lupa beberapa kosakata dan tata bahasa yang sudah dikenal sebelumnya, membuat beberapa jeda dalam ucapannya dan berbicara kata demi kata karena merasa cemas.

A1 takut membuat kesalahan dan kesalahan karena beberapa faktor. Pertama, ia berpikir bahwa latar belakang pendidikan terakhirnya yang hanya sekolah menengah kejuruan lebih rendah daripada sebagian besar temantemannya yang lulus dari universitas. Selain itu, ia berpikir bahwa teman-temannya memiliki pengalaman yang lebih baik dalam belajar bahasa Inggris daripada dirinya. Asumsi ini membuatnya selalu rendah diri tentang kemampuan berbahasa Inggrisnya dan dia tidak dapat menunjukkan performa yang lebih baik dalampercakapan. Selain itu, ia merasa kurang memiliki pengalaman berbicara daripada teman-temannya. Kedua, pengalaman berbicaranya yang buruk menyebabkan dia cemas. Ketika dia mencoba untuk berkomunikasi dengan seorang penutur bahasa Inggris yang membutuhkan informasi tentang transportasi di sekitar 
Jakarta, dia tidak dapat menjelaskan dengan baik karena dia tidak memiliki pelafalan bahasa Inggris dan tidak mengerti apa yang dimaksud oleh penutur asli. Akibatnya, baik dia dan pembicara asli menjadi bingung dan akhirnya, penutur asli mencari yang lain untuk menjelaskan tentang transportasi Jakarta. Kesimpulannya, rendahnya diri akan kemampuan berbicara bahasa Inggris dan pengalaman tidak menyenangkan membuatnya takut membuat kesalahan dan membuatnya cemas. Hal ini tidak hanya ketika berkomunikasi dengan penutur asli bahasa Inggris, tetapi juga dengan seseorang yang dapat berbicara bahasa Inggris. Misalnya, dalam acara resmi, iakhawatir bahwa jika ia membuatkesalahan dalam berbicara bahasa Inggris baik dalam hal tata bahasa dan pelafalan kata-kata, sehingga ada risiko, dan tekanannya lebih tinggi sehingga kegiatan ini membuatnya semakin cemas dibandingkan kegiatan yang lain.

\section{Partisipan A2}

A2 termasuk siswa yang cemas dan sumber FLA utamanya berasal dari ketakutan akan evaluasi negatif. Meskipun dia mendapat FLA seperti menjadi berkeringat dan jantungnya berdebar ketika berbicara bahasa Inggris; kemudian, dia ditertawakan oleh teman-temannya, dia terus merasa percaya diri dan melanjutkan performa berbicara. Secara singkat, menjaga kepercayaan diri adalah strategi mengatasi siswa A2 untuk mengurangi FLA dalam kursus percakapan. Dengan kata lain, untuk mengurangi kecemasan A2 menggunakan perilaku kompromi dengan menjaga kepercayaan diri saat berbicara.

Partisipan A2 adalah dua puluh empat tahun dan latar belakang pendidikan terakhirnya adalah S1 Information Technology (IT). Fokus dari program studi SI adalah merancang, menerapkan, mengembangkan, mendukung atau mengelola sistem informasi berbasis komputer, khususnya aplikasi perangkat keras dan perangkat lunak komputer. Karena itu, dalam studinya, ia mempelajari segala sesuatu yang berkaitan dengan komputer.

Pekerjaan siswa A2 di perusahaan tersebut adalah sebagai Staf Drafter \& 3D yang memiliki beberapa tugas. Pertama, implementasi sketsa adalah gambar detail yang menyertai ukuran dan bentuk detail sebagai referensi pengeksekusi dalam melaksanakan proyek bangunan di lapangan sesuai dengan gambar perencanaan yang telah dibuat sebelumnya. Yang kedua adalah menyesuaikan gambar implementasi dengan kondisi nyata di lapangan. Ketiga, menjelaskan kepada surveyor lapangan tentang implementasi sketsa yang telah dibuat sebelumnya. Terakhir, membuat gambar akhir yang merupakan gambar sebagai laporan tentang implementasi yang telah dibuat di lapangan sebagai pertanggungjawaban kepada pemilik proyek, foto-foto itu dibuat setelah selesainya pekerjaan dan tidak ada perubahan di lapangan.

A2 mengakui bahwa belajar Bahasa Inggris sangat penting baginya karena bahasa Inggris sering ditemukan dalam instruksi program komputer ketika ia menggambar gambar seperti AutoCAD 2D, Ke Max, After Effect, dan Solid Video selama aktivitas kerjanya. Selain itu, ketika dia ingin bekerja dengan aplikasi tersebut, terkadang aplikasi tersebut tidak berfungsi dengan baik atau salah dan dia harus menyelesaikan masalah ini dengan memahami instruksi yang ditulis dalam bahasa Inggris. Olehkarena itu, menguasai Bahasa Inggris diperlukan untuk kegiatan pekerjaan sehari-harinya.

Bahasa Inggris telah dipelajari oleh A2 selama lima belas tahun di lembaga bahasa Inggris formal dan informal. Walaupun bahasa ini telah dipelajari sejak kelas 5 $\mathrm{SD}$, selama pelajaran bahasa Inggris, ia tidak pernah fokus karena ia berpikir bahwa bahasa Inggris bukanlah sesuatu yang sangat penting dalam karirnya walaupun motivasinya dalam belajar bahasa Inggris hanya untuk mengetahui bagaimana berbicara dan mendengarkan bahasa Inggris dengan baik. Selain itu dia juga pernah mendapat pengalaman buruk yang membuatnya gelisah dan cemas ketika berbicara bahasa Inggris. Akibatnya, kemampuan bahasa Inggrisnya rendah dan dia tidak dapat berbicara dengan lancar.

Selama belajar bahasa Inggris di SMA, A2 selalu diminta oleh guru untukberbicara bahasa Inggris di depan teman-temannya. Ketika dia membuat kesalahan, guru tidak memberinya umpan balik positif untuk memotivasi, tetapi guru memarahi dan membuatnya menjadi trauma ketika melakukan hal yang sama. Dia mengakui bahwa dia selalu merasa gugup, sesak napas, keringat dingin, dan ketidakberesan dalam detak jantung ketika berbicara bahasa Inggris di depan orang lain.Dukungan guru adalah variabel yang paling berpengaruh dalam kaitannya dengan kecemasan belajar bahasa [18].

Skor FLCAS A2 adalah 108 dan performanya berbicara selama sesi percakapan menunjukkan beberapa gejala kecemasan yang berarti dia milik siswa yang cemas. Gejala kecemasan yang ditunjukkan oleh seseorang jelas disebabkan hal tertentu. Untuk siswa A2, sumber FLA-nya berasal dari ketakutan akan evaluasi negativeFLA karena pengalaman buruknya terkait dengan berbicara bahasa Inggris di sekolah menengah atas.

Pengalaman buruknya dalam berbicara bahasa Inggris di sekolah menengah atas berdampak negatif pada performa berbicara sehingga membuat beberapa jeda dalam ucapannya dan berbicara kata demi kata. Ucapannya terdengar gagap; dia mengulangi satu kata berkalikali. "I...I...I go to office” Akibatnya, dia merasa gugup, sesak nafas, berkeringat, dan berdebar ketika berbicara bahasa Inggris di depan orang lain sampai sekarang.

MenurutA2, kegiatan berbicara paling membuat dia cemas adalah meninjau ulang pelajaran sebelumnya. Ketika dia diminta oleh guru untuk menjelaskan materi sebelumnya dan dia tidak bisa melakukannya dengan baik, dia merasa cemas.Dia cemas jika temannya menilai dia sebagai siswa tidak pintar dan guru memarahinya karena tidak memperhatikan penjelasannya di pertemuan sebelumnya.

\section{Partisipan A3}

A3 berusia dua puluh enam tahun dan latar belakang pendidikan terakhirnya adalah sekolah menengah atas. Di sekolah menengah atas, bahasa Inggris dipelajari berdasarkan pendekatan berbasis genre dengan mengenali jenis teks terlebih dahulu, kemudian mulai mengidentifikasi struktur generik mereka dan fitur bahasa yang terdiri dari tata bahasa, pemahaman bacaan, dll. Pendekatan ini disebut pendekatan top-down yang berfokus pada latar belakang pengetahuan pembaca untuk memahami materi umum 
kemudian mengidentifikasi bagian - bagian tertentu [19]. Administrator bengkel adalah posisi kerja A3 di perusahaan tersebut. Sebagai administrator bengkel tugasnya menyediakan data atau informasi tentang stok yang diperlukan dan rencana pengiriman tepat waktu dengan mempertimbangkan periode pengiriman dari kantor pusat. Selain itu, dia bertugas menyimpan stok, meminimalkan kerusakannya dan mengoptimalkanpenggunaan ruang penyimpanan serta menulis laporan lokakarya secara berkala.

Bahasa Inggris bagi A3 diperlukan terutama untuk mengoperasikan komputer dalam pekerjaan sehari-harinya. Microsoft Word dan Excel adalah aplikasi komputer yang selalu dia gunakan dalam menulis laporan stok. Perintah dalam aplikasi tersebut menggunakan bahasa Inggris. Jika dia tidak bisa mengerti arti instruksi dalam apikasi, maka dia tidak dapat mengoperasikannya dengan baik dan itu akan berdampak pada keberhasilan lainnya. Selain itu, bahasa Inggris digunakan pada label barang di bengkel dan dia harus menjelaskan spesifikasi barang tersebut kepada klien. Oleh karena itu, menguasai bahasa Inggris sangat penting untuk memfasilitasi pekerjaan sehari-harinya.

Dari pengamatan kelas, siswa A3 menunjukkan beberapa gejala kecemasan diantaranya takut membuat kesalahan, sehingga lupa beberapa kosakata dan tata bahasa yang sudah diketahui sebelumnya. Hasil FLCAS-nya adalah 119 yang berada di antara kisaran 108-123 ang berarti tingkatkecemasan sedang.Dia mengakui bahwa kecemasan tersebut berasal dari ketakutan akan evaluasi negatif.

Evaluasi dan penilaian negatif dari orang lain membuatnya rendah diri dan meremehkan kemampuan berbicaranya akibatnya berdampak pada performa berbicara dalam percakapan. Hal itu, semakin membuat dia cemas diberikan evaluasi dan penilaian negatif dari orang lain. Selama sesi percakapan, dia berbicara dengan hati-hati untuk menghindari membuat kesalahan dan kadangkala menjadi lupa tentang kosakata dan tata bahasa yang telah dipahami sebelumnya. Namun demikian dia percaya bahwa apabila dia bisa berbahasa Inggris dengan lebih baik, maka akan membantunya meningkatkan kepercayaan diriuntuk berkomunikasi dalam bahasa Inggris dengan semua orang. Materi dan aktifitas yang menarik dan menyenangkan akan membantu partisipan mengatasi kecemasan seperti ini..

\section{Partisipan B1}

Sumber utama kecemasannya adalah banyaknya kosa kata baru dalam bahasa Inggris, sehingga dia takut membuat kesalahan. Kegiatan speaking yang membuatnya paling cemas adalah berkomunikasi dengan penutur asli, memahami ucapan penutur asli karena dia berbicara terlalu cepat dan mengikuti tes bahasa Inggris.

Beberapa gejala kecemasan diantaranya membuat jeda dalam ucapannya, berbicara kata demi kata, merasa gugup dan tidak percaya diri. Hasil FLCAS-nya adalah 91, yang berada di kisaran 87-107. Bag B1 membuat kesalahan biasa dalam mempelajari bahasa, karena dengan membuat kesalahan, dia akan belajar dan tidak mengulanginya di masa depan.

Ketika B1 mengikutispeaking test tentang menerangkan furnitur kepada klien dalam kursus percakapan, dia tidak melakukan persiapan yang cukup karena sejumlah pekerjaan lainnyasehinggaterdapat banyak kesalahan dan dia merasa tidak percaya diri saat melakukan presentasi, dan akhirnya, dia menjadi cemas dan gelisah.

Pilihan strategi untuk mengatasi kecemasan berbahasa Inggris. Strategi yang digunakan partisipan dalam mengatasi masalah kecemasan berbahasa asing tergambar pada tabel. Memahami sumber kecemasan berbicara siswa berguna bagi guru untuk mengelompokkan siswa berdasarkan sumber kecemasannya. Meskipun siswa memiliki kecemasan berbicara yang sama di kelas, tetapi sumber kecemasan berbicara yang berbeda membutuhkan tindakan yang berbeda untuk untuk mengatasi dan menyelesaikannya. Menurunnya tingkat kecemasan berbicara dapat meningkatkan kinerja berbicara siswa.

Partisipan yang tidak cemas akan mendapatkan cukup paparan bahasa Inggris dengan mengikuti in house training dengan waktu yang terbatas. Mereka juga meluangkan waktu di luar kelas untuk mendengarkan musik dan menonton film dalam bahasa Inggris. Menonton film dalam bahasa Inggris dapat membantu mahasiswa mendapatkan paparan bahasa yang otentik sehingga kemampuan berbicara dapat ditingkatkan [20]. Selain itu berlatih bahasa Inggris dengan teman sekelas di waktu luang merupakan latihan yang dapat meningkatkan profisiensi berbahasa lisan [21]. Profisiensi berbahasa Inggris lisan sangat dipengaruhi oleh tingkat kecemasa [10]. Dengan kata lain, semakin tinggi kemampuan berbicara bahasa Inggris akan menurunkan tingkat kecemasan berbahasa lisan.

\begin{tabular}{ccc}
\hline Students & The Coping Strategies & Actions \\
\hline $\begin{array}{l}\text { Student A1 } \\
\text { Student A2 Compromise Behavior }\end{array}$ & $\begin{array}{c}\text { Needing a few minutes to make calming down and to } \\
\text { motivate his self by going outside EOP classroom } \\
\text { Keeping confidence while speaking }\end{array}$ \\
Student A3 & Compromise Behavior & $\begin{array}{c}\text { Keeping practicing and studying hard to increase his } \\
\text { confidence in speaking English }\end{array}$ \\
Student B1 Compromise Behavior & $\begin{array}{r}\text { Preparing well before speaking performance and } \\
\text { using positive feedback }\end{array}$ \\
Student B4 Compromise Behavior & $\begin{array}{c}\text { Preparing everything well before performing his } \\
\text { speaking such as brainstorming some expressions } \\
\text { that wanted to be performed }\end{array}$ \\
Student B5 & Compromise Behavior & $\begin{array}{c}\text { Discussing something that was outside the main topic } \\
\text { to catch the audiences' attention before presenting } \\
\text { the main presentation topic }\end{array}$ \\
\hline
\end{tabular}

Bagi guru, sangat berguna untuk memahami strategi mengatasi siswa untuk mengatasi FLA. Seperti disebutkan sebelumnya, seorang siswa dewasa cenderung menggunakan perilaku kompromi untuk mengurangi kecemasan bahasa asing mereka[22]Jika ada salah satu siswa melakukan strategi lain selain perilaku kompromi, guru dapat mendorongnya untuk melakukan perilaku kompromi sebagai strategi efektif untuk mengurangi kecemasan berbicara.

\section{Simpulan}

Temuan pada studi ini diantaranya adalah latar belakang pendidikan lamanya pembelajaran bahasa Inggris, dan pengalaman belajar sebelumnya tidak memiliki korelasi dengan Kecemasan Bahasa Asing (FLA). Namun, ada hubungan antara pengalaman dalam berkomunikasi dan FLA.Siswa yang memiliki pengalaman buruk ketika berkomunikasi di masa lalu, akan mengalami kecemasan ketika mendapatkan situasi serupa di masa depan. Dengan 
kata lain, pengalaman buruk dalam berkomunikasi berdampak pada kecemasan berbahasa (Humpries, [23]). Beberapa faktor yang membuat siswa santai selama sesi percakapan adalah motivasi belajar, dan mendapatkan eksposur yang cukup; di sisi lain, pengalaman buruk dan takut membuat kesalahan dan kesalahan adalah beberapa faktor yang membuat siswa merasa cemas. Untuk mengurangi kecemasan siswa dan meningkatkan keterampilan berbicara diperlukan kerja sama antara guru, siswa dan pemangku kepentingan perusahaan.

Dengan mengenali tingkat kecemasan yang dialami oleh partisipan dalam pelatihan in-house kelas bahasa Inggris, para siswa dapat lebih sadar tingkat kecemasan apa yang mereka alami dan menyadari bahwa kecemasan adalah salah satu faktor yang mempengaruhi keberhasilan belajar bahasa asing dan dapat menghambat perkembangan kemampuan berbicara. Untuk seorang guru, sangat berguna untuk memahami jika satu kelas terdiri dari berbagai karakteristik, latar belakang pendidikan, dan pengalaman siswa dalam mengalami kecemasan. Keyakinan guru tentang belajar bahasa akan menentukan bagaimana mereka membantu siswanya menguasai strategi belajar bahasa Inggris [14]. Oleh karena itu, strategi mengatasi kecemasan dapat menjadi masukan yang baik sebagai pertimbangan untuk melakukan tindakan selanjutnya dalam merencanakan proses belajar mengajar.

\section{Kepustakaan}

[1] Irawan, R., Warni, S., Wijirahayu, S. EFL Learners' Speaking Anxiety in an EOP Program. Journal of ELT Research. Vol. 3, No. 2, 2018 JER_Vol 3 Issue2 (2018)

[2] Qunying, Zhang.Conceptions of a Good English Language Teacher at Tertiary Level in the People's Republic of China.http://hub.hku.hk/bitstream/10722/51247/6/FullText.pdf?acce $\mathrm{pt}=1$ (2007)

[3] Horwitz, E. K., Horwitz, M. B., \& Cope, J. Foreign language classroom anxiety. Modern Language Journal, 70(2), 125 32.http://hyxy.nankai.edu.cn/jingpinke/buchongyuedu/foreign\%20la nguage\%20classroom\%20anxiety.pdf (1986)

[4] Brown, H. Douglas. Principles of Language Learning and Teaching. New York: Addison Wesley Longman Inc.(1987)

[5]Spratt, Mary et al.The TKT Course. Cambridge: Cambridge University Press. (2005)

[6] Cameron, L. Teaching Languages to Young Learners. Cambridge: Cambridge (2001)

[7] Richard-Amato, P. A. 2003. Making It Happen: Fro Interactive to Participatory Language Teaching. White Plains, NY: Longman.

[8] Alim, E.S., Umam, K. \& Wijirahayu,S. The Imlementation of Blended Learning Instruction by Utilizing WeChat Application. Proceeding of the $24^{\text {th }}$ International Conference on Computers in Education ICCE (100- 107) 2016.
[9] Aling, Cynthia. A Study on ESL and EFL Students' Language Anxiety In A Native Speaking Environment. E-Proceeding of The 4th Global Summit On Education 2016.

[10] Wu, Kun-huei. The Relationship between Language Learners' Anxiety and Learning Strategy in the CLT Classrooms.http://files.eric.ed.gov/fulltext/E J1066074.pdf (2010)

[11] Batiha, Jafar et al. Exploring the Factors of Classroom Anxiety in the Context of EFL Arab Students. (2014)

[12] Ganschow, L. \& Sparks, R. Anxiety about Foreign Language Learning Among High School Women. Modern Language Journal, 80(2), 199- 212.http://www.jstor.org/stable/328636 (1996)

[13] Chan, Daniel Yu-ching \& Guo-cheng Wu. A Study of Foreign Language Anxiety of EFL Elementary School Students in Taipei County. National Taipei Teachers College: Journal of National TaipeiTeachers College, Vol.17, No.2, 287 320.http://academic.ntue.edu.tw/ezfiles/7/1007/img/41/17-212.pdf (2004)

[14] Wijirahayu, S. Strategi Belajar Bahasa Inggris sebagai Bahasa Asing dari Perspektif Keyakinan Guru. Proceeding Konferensi Nasional Pascasarjana PTM ke-5 di Sidoarjo 2017.

[15] Young, Dolly Jesusita. Creating a Low-Anxiety Classroom Environment: What Does Language Anxiety Research Suggest? TheModern Language Journal, Vol. 75, No. 4, Pp. 426-439. Blackwell Publishing on Behalf of the National Federation of Modern Language Teachers Associations. Http://www.Jstor.Org/Stable/329492. (1991)

[16] Alshahrani, Merzin \& Awad Alshahrani. An Investigation of Anxiety Among Elementary School Students Towards Foreign Language Learning.http://cscanada.net/index.php/sl1/article/download/7180/77 77. (2011)

[17] Cha, Haekyung. Korean Elementary ESOL Students' English Language Anxiety and Defense Mechanism in the ESOL and Mainstream Classes: Theoretical and Pedagogical Implications for TESOL. (Electronic Theses, Treatises and Dissertations.). The Graduate School, The Florida State University, Florida.(2006)

[18] Huang, Shufen et al. The Relationship between Teacher and Peer Support and English-Language Learners' Anxiety.http://files.eric.ed.gov/fulltext/EJ108142 9.pdf. (2010)

[19] Debat, Elba Villanueva de. Applying Current Approaches to the Teaching of Reading. https://americanenglish.state.gov/files/ae/resource_files/06-44-1c.pdf. (2006)

[20]Wijirahayu,S.Pre-Service Teacher's Beliefs in Utilizing Film and $\begin{array}{llll}\text { Role-Play in EFL Classroom Practices. } & \text {. }\end{array}$ https://www.academia.edu/7837048/PRE-

SERVICE_TEACHERS_BELIEFS_IN_UTILIZING_FILM_AND_R OLE-PLAY_IN_EFL_CLASSROOM_PRACTICES.2014

[21] Khetaguri, Tamuna \& Mustafa Albay. The Use of Drills in the Development of Speaking Skills.http://ijsses.org/wpcontent/uploads/2017/01/The-Use-of-Drills-in-the-Development-ofSpeaking-Skills1.pdf. (2016)

[22] Wijirahayu, S. \& Dorand, P.2018.Affective Strategies, Attitude and A Model of Speaking Performance Development for Engineering Students. Journal of Physic Conference series 948 (2018) 012024

[23] Humphries, Rebecca. Language Anxiety In International Students: How can It be Overcome? Https://Www.Griffith.Edu.Au/ Data/Assets/Pdf File/0 004/ 384061/ Humphries-Language-Anxiety.Pdf (2011) 